\title{
SMARTPHONE-BASED ANALYSIS OF CLOTH MASKS PORES SIZE
}

\author{
Meri Hamdini, Diana Novita Sari, Susanti, and Yuant Tiandho* \\ Department of Physics, Universitas Bangka Belitung \\ Jl. Kampus Peradaban, Bangka, Kep. Bangka Belitung 33172, Indonesia
}

Received: $29^{\text {th }}$ July 2021; Revised: $15^{\text {th }}$ November 2021; Accepted: $15^{\text {th }}$ December 2021

\begin{abstract}
Until now, the world is still facing the spread of the SARS-CoV-2 virus that causes COVID-19. This virus can be transmitted from human to human through droplets, so more vigilance is needed to avoid contracting this virus. One of the steps to minimize the spread of Covid-19 is to wear a face mask. In practice, most people prefer to use cloth masks than disposable medical masks because they are cheap and reusable. Cloth pore size influences the filtering ability of the cloth masks. Therefore, it is necessary to analyze the efficiencies of the cloth masks. In this study, we developed a method for measuring the pores of a cloth mask using a smartphone. In this study, we developed a method for measuring the pores of a cloth mask using a smartphone. We used the camera zoom application on a smartphone and analyzed the image using image processing software, ImageJ. We applied Huang's algorithm to adjust the image binarization threshold then calculated the Feret diameter as the pore size of the mask. According to the analysis, the pore size ranged from 0.133 to $0.232 \mathrm{~mm}$, and the efficiency ranged from 77.4 to $82.6 \%$.
\end{abstract}

Keywords: Covid-19; Cloth masks; Filtration efficiency; Smartphone

\section{Introduction}

Most of the diseases that threaten human health come from an unhealthy environment. One indicator of environmental quality is often associated with the level of air cleanliness. ${ }^{1}$ In addition to pollutants, the air is also an intermediary for several diseases, so prevention is necessary to minimize the spread. Especially at this time, the world is shocked by the COVID-19 disease caused by a new type of coronavirus called SARS-CoV$2 .^{2}$ Various studies have stated that COVID19 can spread through patient droplets to people around them. ${ }^{3}$ Therefore, we need equipment to prevent the COVID-19 virus or other pollutants from being inhaled into the respiratory system.

Following the health protocol, one of the steps to minimize and curbing the spread of COVID-19 is to wear a face mask. ${ }^{4,5} \mathrm{~A}$ face mask is one of the PPE (Personal Protective Equipment) that is needed and even mandatory for everyone to use during this pandemic, especially people who do activities

\footnotetext{
*Corresponding author.

E-Mail: yuant@ubb.ac.id
}

outside the home. ${ }^{6}$ The use of a face mask protects the respiratory system, especially the nose and mouth. Thus, wearing a face mask can protect us from the droplets released by COVID-19 patients. $^{7}$ Several face masks are currently used in society, such as N95 masks, surgical masks, and cloth masks. ${ }^{8}$ N95 masks and surgical masks are medical masks with standardized filtration capabilities. However, both masks are disposable, so long-term use for the general public tends to be uneconomical and prone to producing medical waste. Therefore, the use of cloth masks for society is expected to answer these challenges because cloth masks can be washed and can be used repeatedly. ${ }^{2}$

The level of filtration efficiency of a cloth mask depends on its pore size. ${ }^{9}$ The smaller the pore size, the higher the filtration efficiency. It means the success rate for minimizing inhaled particles or droplets is also higher. The problem is, there are various types of cloth masks currently used in society. These cloth masks are made of different materials and different techniques, and it 
affects their pore size. On the other hand, most cloth masks in the market do not include data on the pore size of the cloth mask on the packaging. Therefore, it is necessary to analyze the pore size of the cloth mask used.

Usually, face mask pore measurements are carried out using a microscope. However, not all people have it. In this work, we proposed an alternative method to measure the pore size of cloth masks using a smartphone. We used a camera zoom application and integrated it with a simple image processing application.

\section{Methods}

The cloth masks used in the study were obtained in Pangkalpinang City. Five types of cloth masks with different types of cloth were photographed using a smartphone camera (OPPO A1K). We used magnification application which is downloaded in the app store with the name "Magnifier Zoom Microscope" to get a precise pore shape, which can magnify up to 10 times. The process of taking photos of cloth masks was carried out at a distance of $10 \mathrm{~cm}$, and the back of the cloth mask was irradiated with a light source from smartphone camera. The scheme of the process is shown in Figure 1. The pore image of the cloth mask was analyzed using Image J software. To convert the meter scale into pixels and vice versa, we also took a photo of the ruler under the same conditions. The pore detection process is carried out automatically after going through the image binarization process by using Huang's algorithm. The pore size of the cloth mask measured in this study is analogous to the Ferret diameter. Furthermore, through the obtained pore size, the efficiency value of cloth masks in filtering particles is calculated based on the research of Neupane et al. (2019), which examines the relationship between pore size and efficiency of face masks. ${ }^{11}$

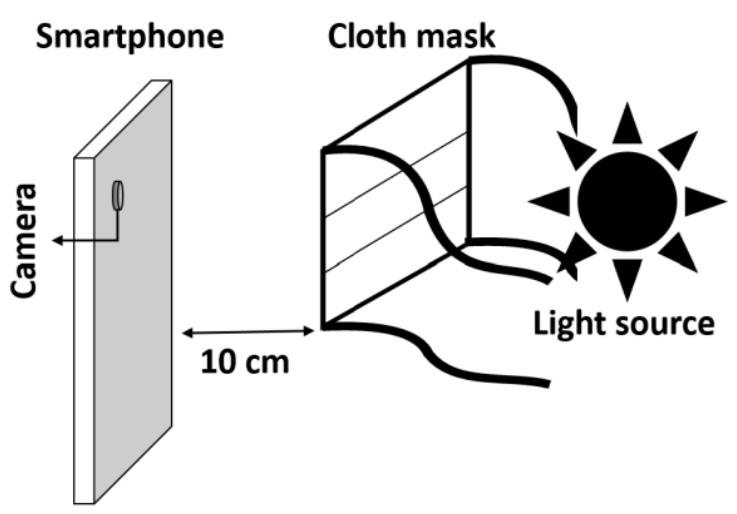

Figure 1. The process of taking photos of cloth masks

\section{Result and Discussion}

The five masks analyzed were the most commonly found cloth masks on the market in Pangkalpinang City. It appears that cloth masks have various shapes, as shown in Figure 2. Cloth masks B, C, and D have folds, while cloth masks A and B have no folds. In addition, the five cloth masks are made of different materials, i.e., t-shirt fabric (a), spandex fabric (b), cotton (c), diamond fabric (d), and scuba fabric (e).

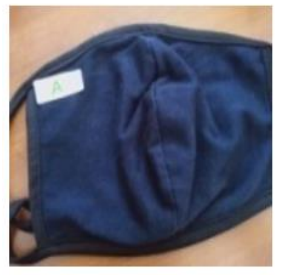

(a)

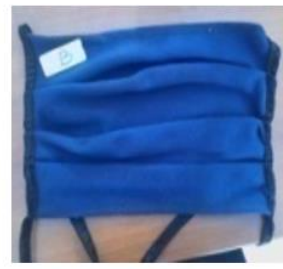

(b)

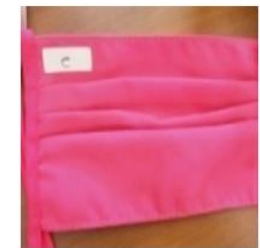

(c)

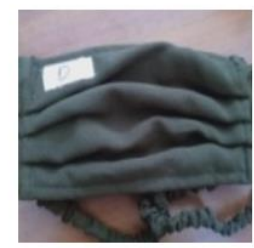

(d)

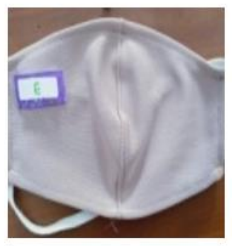

(e)

Figure2. Sample of cloth masks: (a) t-shirt fabric, (b) spandex fabric, (c) cotton, (d) diamond fabric, and (e) scuba fabric.

Due to the small pore size of cloth masks, a microscope is needed to observe the pores conventionally. Therefore, we propose a measurement method with a smartphone because applications act as magnifying glasses. It can be an alternative method in 
determining the pore size of cloth masks which previously could only be done in the laboratory. The results of the pore image using the Magnifier Zoom Microscope application are shown in Figure 3. Cloth masks made of t-shirt material appear to have the finest mean pore sizes, while cloth masks made of cotton, spandex fabric, and scuba fabric have the larger mean pore size

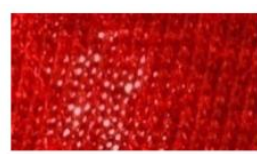

(a)

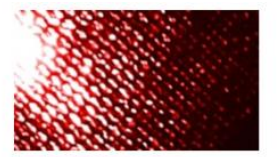

(b)

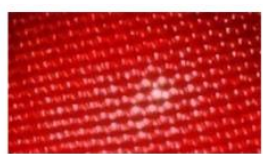

(c)

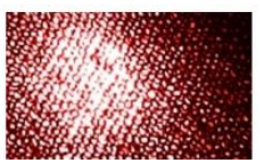

(d)

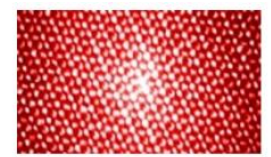

(e)

Figure 3. Cloth masks pore structure: (a) t-shirt fabric, (b) spandex fabric, (c) cotton, (d) diamond fabric, and (e) scuba fabric.

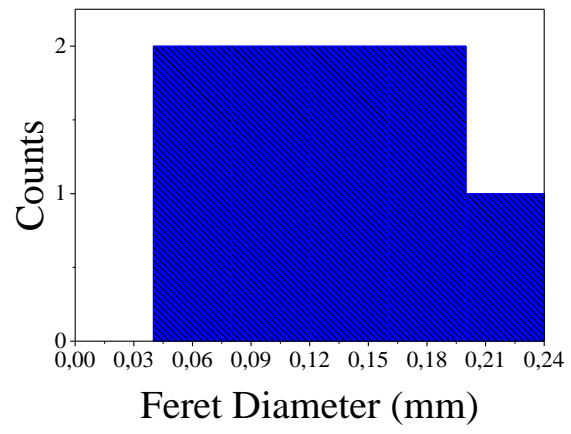

(a)

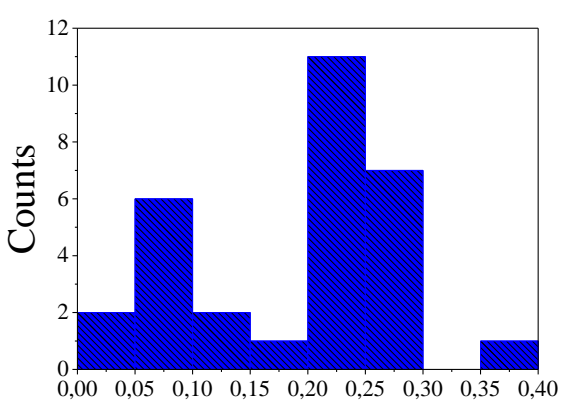

Feret Diameter $(\mathrm{mm})$

(c)

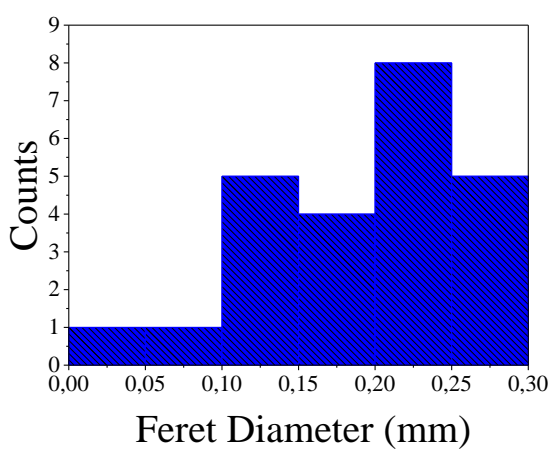

(b)

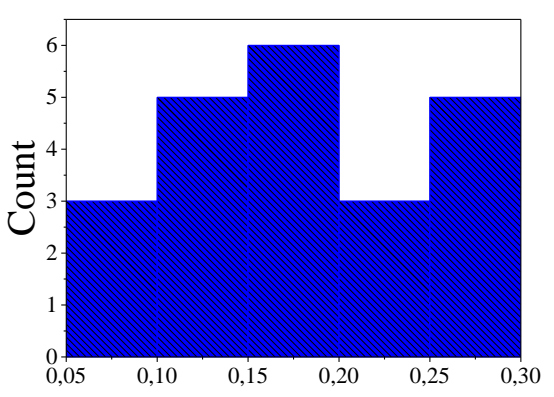

Feret Diameter (mm)

(d)

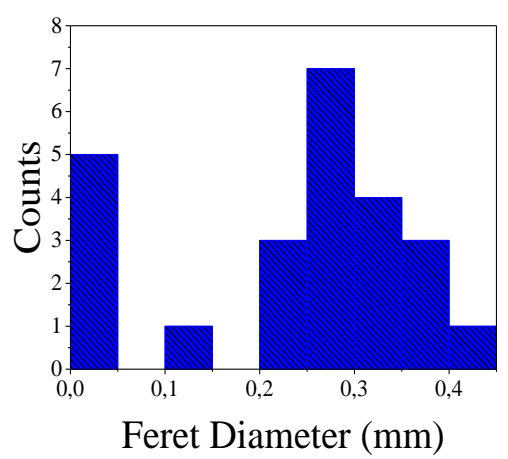

(e)

Figure 4. Distribution of pore size of cloth masks: (a) t-shirt fabric, (b) spandex fabric, (c) cotton, (d) diamond fabric, and (e) scuba fabric. 


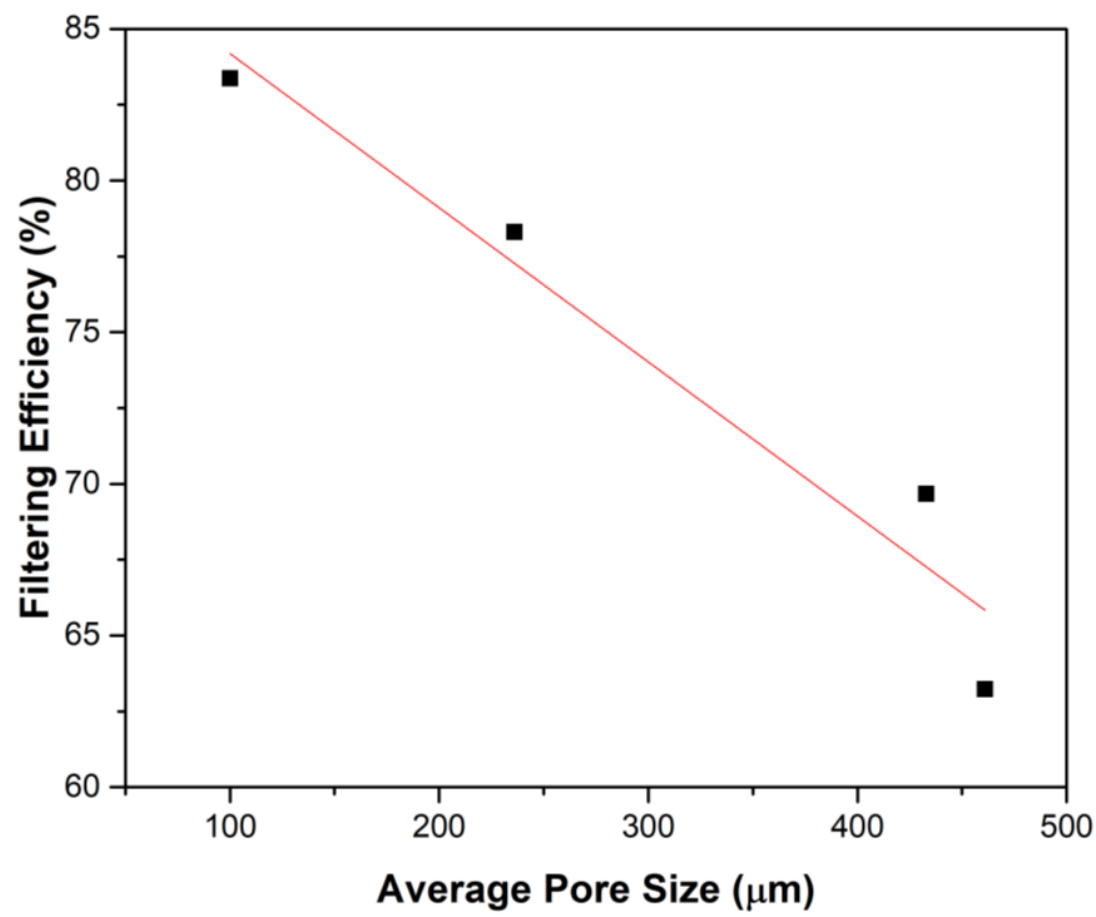

Figure 5. The relationship between the pore size of a cloth mask and its filtration efficiency, according to Naupene's research (2019) ${ }^{11}$

Table 1.The average size of the pore size of cloth masks

\begin{tabular}{lc} 
Type of Mask & Feret Diameter $(\mathbf{m m})$ \\
\hline T-shirt fabric & 0.133 \\
Spandex fabric & 0.191 \\
Cotton & 0.194 \\
Diamond fabric & 0.179 \\
Scuba fabric & 0.232 \\
\hline
\end{tabular}

Through the pore image of cloth masks at 10x magnification, we analyzed the pore size of the cloth mask quantitatively. We use ImageJ software which is widely used in the field of image analysis for both material engineering and medical purposes. The advantage of ImageJ compared to other image processing applications is that this application is open source and easy to use. In addition, smartphone users can use ImageJ online via the page: https://ij.imjoy.io/.

Cloth mask pores have various shapes (not round). Therefore, to ensure that the pores can or cannot be passed through the other particles, we used the Feret diameter. ${ }^{10}$ Feret diameter is one of the parameters used to identify particles sized in various shapes. ${ }^{10}$
The pore size distribution results of each mask are shown in Figure 4. Based on Figure 4, the average pore sizes were obtained and presented in Table 1. In this study, we found that the pore size distribution was in the range of $0.133 \pm 0.104 \mathrm{~mm}$ to $0.232 \pm 0.056 \mathrm{~mm}$. The masks made of $t$-shirt fabric have the lowest pore size values compared to others. The scuba fabric cloth mask has the largest pore size, which was $0.232 \mathrm{~mm}$. Scuba fabric has an elastic texture so that when pulled or used it causes the pores of the fabric to become larger. ${ }^{12}$

The pore size of cloth masks is essential to know because it determines the level of efficiency of the mask in carrying out filtration. Based on Neupane's research data, 
which examines the relationship between the pore size of a cloth mask and its efficiency, ${ }^{11}$ we analyzed the data through fittings to obtain a more precise mathematical relationship. Through fitting with the linear fit, we obtain the relationship between the pore size of the cloth mask (PSCM, $\mu \mathrm{m})$ and its filtration efficiency $(\mathrm{FE}, \%)$ as,

$$
F E=89.274-0.051 P S C M
$$

Table 2. Filtration efficiency of cloth masks

\begin{tabular}{lc}
\hline Type of Mask & Filtration Efficiency (\%) \\
\hline T-shirt fabric & 82.6 \\
Spandex fabric & 79.5 \\
Cotton & 79.4 \\
Diamond fabric & 80.2 \\
Scuba fabric & 77.4 \\
\hline
\end{tabular}

Figure 5 shows the level of conformity between the experimental data and the fittings performed. The coefficient of determination obtained is $R^{2}=0.94$. It appears that the proposed model has good accuracy in describing the relationship between the two variables. The smaller the pore size of the cloth mask, the better the filtering efficiency because the mask blocks more particles.

According to the relationship between the pore size of cloth masks and their filtration efficiency, as in equation (1), we can determine the level of filtration efficiency of the cloth masks we studied, as presented in Table 2. It appears that the filtration efficiency of cloth masks is in the range of $77.4 \%$ to $82.5 \%$. The value of filtration efficiency is in the filtration effectiveness range of cloth masks, which is from $3 \%$ to $95 \%{ }^{13}$. A cloth mask made of a t-shirt is a cloth mask with the highest level of filtration efficiency, while a mask made of scuba fabric is a cloth mask with the lowest level of filtration efficiency. Although it is comfortable to use, scuba masks are not very effective in preventing the transmission of Covid-19. ${ }^{14,15}$

However, what should also be noted is the relationship between the pore size of cloth masks and their filtration efficiency, which was carried out in this study based on the work done by Naupene et al. (2019). In their research, they tested the efficiency of passive filtration without considering the human inhalation aspect. In addition, the ability of the fabric to hold droplets of liquids was not considered in this study. However, it is hoped that this research can be an alternative solution to determine the filtering efficiency of cloth masks based on their pore size and the ability of the mask to hold droplets can be conducted in other studies.

\section{Conclusion}

In this study, we have succeeded in proposing an alternative method of measuring the pores of a cloth mask using a smartphone. The use of camera magnification applications, such as the Magnifier Zoom Microscope, can improve the clarity of the pore structure of fabric masks. It is because the application allows users to zoom up to 10x. The pore image analysis process using ImageJ can be done quickly, and it can be conducted through an online platform. Besides having different shapes, cloth masks with different materials also have different pore shapes. The pore size range in this study is in the range of $133 \mu \mathrm{m}$ to $232 \mu \mathrm{m}$. Thus, the filtration efficiency of cloth masks is in the range of $77.4 \%$ to $82.6 \%$. Cloth mask made of t-shirt fabric is cloth masks with the highest filtration efficiency, and cloth mask made of scuba fabric has the worst filtration efficiency. Furthermore, to improve the performance analysis of cloth masks, it is necessary to develop methods to test the ability of cloth masks to hold droplets. 


\section{Acknowledgment}

This research is funded by The Ministry of Education, Culture, Research, and Technology through scheme: PKM-RE in 2021.

\section{References}

1. Faisal HS., Susanto AD. Peran Masker/Respirator dalam Pencegahan Dampak Kesehatan Paru Akibat Polusi Udara. Jurnal Respirasi. 2017 Jan; 3(1): 17-25.

2. Rohmawati UR. Optimalisasi Filtrasi Masker Kain Dengan Filter Catridge Dari Limbah Sabut Kelapa Untuk Mewujudkan Sustuinable Development Goals 2030. Prosiding Seminar Nasional Biologi di Era Pandemi COVID-19; 2020 Sep 19; Gowa, Indonesian. Journal UIN Alaudin;2020.P.441-448.

3. Diarti MJ, Jiwintarum Y, Dramawa A. 2020. Edukasi Masyarakat Melalui Aktivitas Relawan Non Medis Dalam Memutus Rantai Penyebaran Covid-19 di Lingkungan Cakranegara Utara. Jurnal Pengabdian Masyarakat Sasambo. 2020 Nov; 2(1): 150-154.

4. Putri SI. Studi Literatur: Efektivitas Penggunaan Masker Kain dalam Pencegahan Transmisi COVID-19. Jurnal Kesehatan Manarang. 2020 Oct;6: 09-17.

5. Teesing GR, Straten BV, Man PD, and Horeman-Franse T. Is There an Adequate Alternative to Commercially Manufactured Face Mask? A Comparatioan of Various Materials and Forms. Journal of Hospital Infection. 2020;106: 246-253.

6. Sunaryo D. Pembuatan Masker Kain Sebagai Pencegahan Penularan Virus serta Mengoptimalkan Pendapatan di Masa Pandemi COVID-19 bagi Masyarakat di Desa Sukaratu. Jurnal ABDIDAS. 2020;4: 183-192.

7. Theopilus Y, Yogasara T, Theresia C, Octavia JR. Analisis Risiko Produk Alat Pelindung Diri (APD) Pencegah Penularan COVID-19 untuk Pekerja
Informal di Indonesia. Jurnal Rekayasa Sistem Industri. 2020 Jul;9(2): 115-134.

8. Mayasiana NA. Pelatihan Pembuatan Masker Kain 3 Lapis untuk Pencegahan COVID-19. Pelita Ilmu. 2020 Jun;3(1): 60-74.

9. Neupane BC. A smartphone microscopic methode for rapid screening of cloth facemask fabrics during pandemics. [Pdf]. 2020. Available from: https://peerj.com/articles/9647.

10. Igathinathane $\mathrm{C}$, et al. Shape identification and Particles Size Distribution from Basic Shape Parameters Using ImageJ. Computers and Electronics in Agriculture. 2008 Feb;63:168-182.

11. Neupane BB, Mainali S, Sharma, A., and Giri B. Optica; microscopic study of surface morphology and filtering efficiency of face masks. PeerJ. 2019, 7412. Available form: https://peerj.com/articles/7142

12. Wahyuningsih SE, Naam MF, Widihastuti W, Agustin EW, and Ayuningtyas I. Quality analisis of non medical fabric in terms of convenience, air permeability and sterilization. IOP Conference Series: Earth and Environmental Science. 2021 Sep 1920.P. 1-11.

13. Sunjaya AP, and Morawaska L. Evidance Review and Practice Recommendation on the Material, Design, and Maintenance of Cloth Masks. Cambridges Journals. 2020 Sep;14(5): 42-46.

14. Atmojo JT, et al. The Use of Masks in the Prevention and Management of COVID19: Rationality, Effectiveness and Current Issues. Avicenna: Journal of Helath Research. 2020 Oct;3(2): 84-95.

15. Kusuma UF, et al. Analisis Penelusuran Masker Sebagai Protokol Kesehatan saat Pandemi Covid-19 di Indonesia: Studi Google Trends. VisiKes: Jurnal Kesehatan. 2021 Apr;20(1): 98-108. 